\title{
Comparative Anatomy and Morphology of the Leaves of Grenache Noir and Syrah Grapevine Cultivars
}

\author{
P. Gago ${ }^{*}$, G. Conejero' , M. C. Martínez ${ }^{1}$, P. This ${ }^{3}$, J. L. Verdeil ${ }^{2}$
}

(1) Misión Biológica de Galicia (MBG-CSIC), Consejo Superior de Investigaciones Científicas, Salcedo 36143, Pontevedra, Spain

(2) Centre de Coopération Internationale en Recherche Agronomique pour le Développement (CIRAD), Institut National de la Recherche Agronomique (INRA) Montpellier SupAgro, Histocytology \& Plant Cell Imaging Platform (PHIV), UMR Ameliorat Genet \& Adaptat Plantes, Montpellier, France

(3) Institut National de la Recherche Agronomique (INRA), UMR 1334, AGAP, Equipe Divers Adaptat \& Ameliorat Vigne, F-34060 Montpellier, France

Date of submission for publication: June 2018

Date of acceptance for publication: November 2018

Key words: Calcium oxalate, idioblasts, leaf anatomy, leaf morphology, stomata, Vitis vinifera

\begin{abstract}
Grenache Noir and Syrah are two of the grapevine (Vitis vinifera $\mathrm{L}$.) cultivars used to a great extent worldwide. They have very different leaf morphologies from an ampelographic (botanical) point of view. This might also be related to differences in the anatomy and micro-morphology of their leaves. The goal of the present work was to compare these cultivars' leaf anatomy and morphology. Adult leaves from both cultivars were characterised using a range of microscopy techniques. Grenache Noir had a significantly smaller leaf surface area, but a significantly thicker leaf blade, than Syrah. It also had significantly larger stomata and a larger stomatal index than Syrah. The distribution of mesophyll tissues was similar in both cultivars, but the upper epidermis was significantly thicker in Grenache Noir, and the palisade parenchyma cells were longer in Syrah. The mesophyll tissues of both cultivars contained abundant idioblasts carrying crystals of calcium oxalate and mucilage. This work reveals quantitative and qualitative differences in the anatomy and morphology of mature Grenache Noir and Syrah leaves. Further work is needed to determine how these anatomical and morphological differences may be connected with different responses at the functional level.
\end{abstract}

\section{INTRODUCTION}

The grapevine (Vitis vinifera L.) cultivars Grenache Noir and Syrah (synonym Shiraz) occupy the seventh and sixth places respectively in the world ranking of area given over to grapevine cultivation and wine production (Anderson \& Aryal, 2013). Both cultivars have been used as parentals in producing segregant populations for constructing the grapevine genetic map (Vezzulli et al., 2008), and as model cultivars for studies on grapevine ecophysiology and resistance to biotic and abiotic stress (Schultz, 2003; Boso et al., 2010; Coupel-Ledru et al., 2014).

In recent years, $V$. vinifera has been used as an example for the study of the cultivar effect on ecophysiological responses and stomatal control under conditions of water stress (Schulz, 2003; Lovisolo et al., 2010; Tombesi et al., 2014; Hochberg et al., 2018). Tardieu and Simonneau (1998) classified grapevine cultivars as iso/anisohydric, based on their ability to regulate leaf water potential $\left(\Psi_{\mathrm{L}}\right)$, and other authors later classified Grenache Noir as isohydric, i.e. when little water is available, its leaf water potential $\left(\Psi_{\mathrm{L}}\right)$ is maintained via the increased regulation of stomatal conductance $\left(\mathrm{g}_{\mathrm{s}}\right)$. For this reason, the Grenache Noir cultivar is therefore considered drought resistant (Hugalde \& Vila, 2014). Syrah, in contrast, has been classified as anisohydric, since its $\Psi_{L}$ falls under water stress conditions and the stomata are not regulated much (Schultz, 2003; Santesteban et al., 2009). However, this dichotomy between iso/ anisohydric has been long questioned (Martínez-Vilalta \& García-Former, 2017; Hochberg et al., 2018). According to these authors, an implicit assumption of describing specific grapevine cultivars as being iso/anisohydric is that plant hydraulic behaviour is determined solely by the genotype and does not take into consideration the large effect of the environment (Hochberg et al., 2018) and key tissue traits of the rhizosphere or xylem in water relations (Martínez-Vilalta \& García-Former, 2017).

It has been shown in different plant species that the anatomical characteristics of the leaf epidermis and mesophyll have a direct bearing on the capacity to adapt to the environment (Ennajeh et al., 2010; Ben Salem-Fnayou et al., 2011; Liu et al., 2015; Doupis et al., 2016). However,

\footnotetext{
*Corresponding author: E-mail address: pgago@mbg.csic.es

Acknowledgements: This work was funded by a fellowship from the Fundación Barrié (Spain). We thank the staff of the PHIV facility (http://phiv.cirad.fr), for their technical assistance and helpful discussions, and Elena Zubiaurre (MBG-CSIC), for assistance with the photographic plates
} 
while the differences in the behaviour of Grenache Noir and Syrah under water stress conditions have been studied from a functional response/physiological standpoint, no studies have compared the anatomical and morphological features of their leaves. In previous work (Gago et al., 2016), our group reported microanatomical differences between other grapevine cultivars related to their trichomes. The present work extends this study by examining, using different microscopy techniques, the differences in the anatomy and morphology of Grenache Noir and Syrah leaves. Knowledge of such differences may throw light on these cultivars' different responses to water stress.

\section{MATERIALS AND METHODS \\ Plant material}

The analysed leaves belonged to five plants each of the Grenache Noir clone 344MT6 and Syrah clone ENTAV73. Non-grafted plants of these two cultivars are maintained in a sandy soil under a 'cordon trained to an espalier' canopy system (3 300 plants/ha plant density) with irrigation at the Montpellier SupAgro Domaine du Chapitre Experimental Plantation (Hérault, France). All leaves $(\mathrm{n}=10$ per cultivar [two per plant]) were collected from nodes 8 to 9 of a fruiting cane growing from the present year's wood, after fruit-setting and before véraison (when leaf development is complete). The areas of the leaf lamina selected for stomatal and anatomical examination and morphometric measurements (Fig. 1) were chosen according to the recommendations of D’Ambrogio de Argüeso (1986) and Scienza and Boselli (1981).

\section{Leaf variables studied \\ Total leaf surface area}

Digital images (black and white; 600 ppi) were obtained for five leaves per cultivar, and the mean surface area of the blades was determined.

\section{Density of stomata and stomatal index}

Using nail polish, three prints of the same area of the lower side of the leaf were taken from three of the five leaves per cultivar sampled, as described previously (Fig. 1). When the polish had completely dried at room temperature, it was pulled off with the help of adhesive tape and placed on a microscope slide. These preparations were then photographed (magnification X 20) in two different places using a Leica DM4500 microscope (Leica, Germany) equipped with a Retiga 2000R camera (QUIMAGING, Canada) (performed at the Montpellier Imaging Facility, www.mri.cnrs.fr) running Volocity ${ }^{\circledR}$ image capture software (Improvision, UK). The number of stomata and epidermal cells in the two photographs were then counted and the stomatal index determined according to Wilkinson (1979):

$$
\mathrm{SI}=(\mathrm{NS} * 100) /(\mathrm{NC}+\mathrm{NS})
$$

where

$\mathrm{SI}=$ stomatal index

$\mathrm{NS}=$ number of stomata in the field of view (unit area)

$\mathrm{NC}=$ number of epidermal cells in the same field of view (unit area)

Finally, stomatal length was measured for all the stomata visible in each of the nail polish prints.

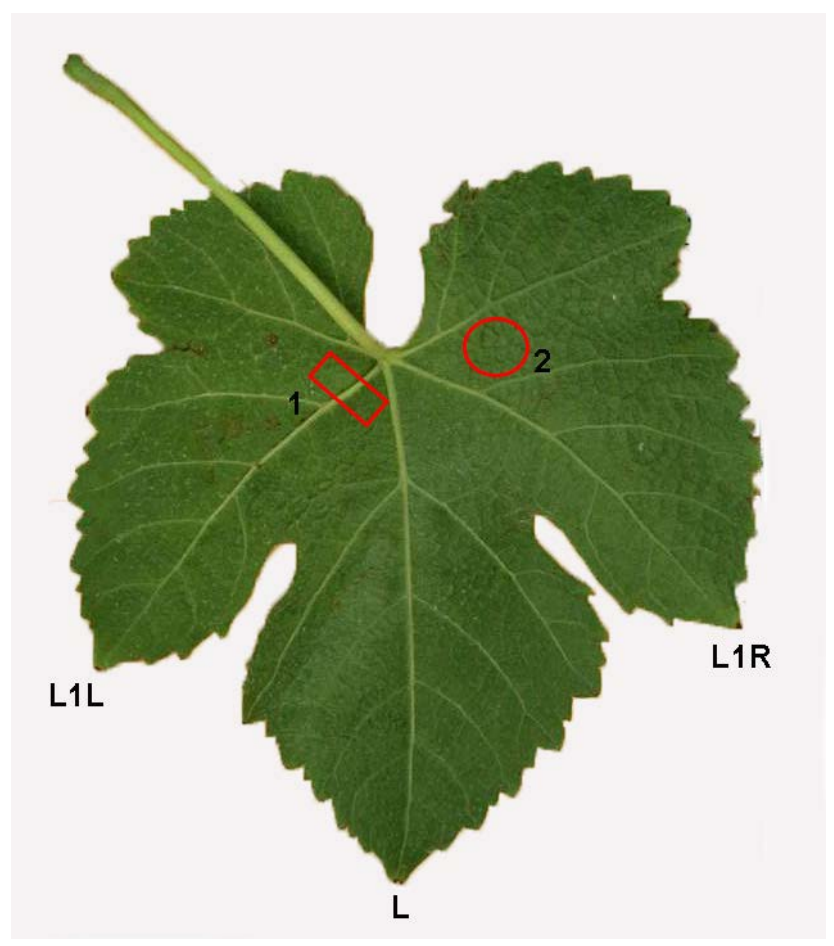

FIGURE 1

Parts of the leaf blade from where samples were taken for microanatomy studies: (1) for the determination of stomatal density, (2) for the determination of stomatal index. The sampling areas were chosen according to the recommendations of D'Ambrogio de Argüeso (1986) and Scienza and Boselli (1981). 


\section{Leaf anatomy}

Immediately after collecting the leaves, the petiole was wrapped in a wet paper towel and put in a plastic bag and inside a cooler. They were transported to the laboratory and, on the same day, a $0.3 \times 1 \mathrm{~mm}$ sample was taken from the area of the leaf, as shown in Fig. 1, and immediately fixed in formaldehyde; this was performed for five leaves per cultivar. Each sample included a portion of vein L2 and some of the blade from either side. These samples were fixed, dehydrated and embedded in resin, as previously described in Gago et al. (2016), and the blocks were cut transversally and longitudinally using a Leica RM2255 microtome (Leica, Germany) to provide $3.5 \mu \mathrm{m}$ sections. The latter were doublestained for carbohydrates and proteins using periodic acid Schiff reagent (PAS) and naphthol blue-black reagent (NBB) (Fisher, 1968; Buffard-Morel et al., 1992), and mounted in Isomount (Labonord, France). Digital images (magnification $x$ 20) were then acquired using a NanoZoomer 2.0 HT digital slide scanner (Hamamatsu, Japan) at the same Montpellier Imaging Facility and viewed using NDPview software. The same preparations were also viewed by epifluorescence microscopy using a Leica DM 6000 microscope (Leica, Germany) under bright field conditions and employing the A-type filter (450 to $490 \mathrm{~nm}$ ). Images were recorded at different magnifications using a Retiga 2000R (QIMAGING, Canada) camera running Volocity ${ }^{\circledR}$ software (Improvision, UK).

The following variables were then measured:

- Total leaf blade thickness

- Thickness of the upper epidermis, the palisade parenchyma, spongy parenchyma and lower epidermis

- Upper and lower cuticle thickness

- Area of the spongy parenchyma occupied by lacunae

- Stomata guard cell area (measured when stomata transverse sections were complete)

- Distribution of idioblasts in the mesophyll and size of crystals carried

\section{Image analysis}

ImageJ software (National Institutes of Health, MD, USA http://rsbweb.nih.gov/ij/) was used to take all measurements and do all counts.

\section{Statistical analysis}

Means for the different variables were compared using Student's t-test for independent samples. Significance was set at $P \leq 0.05$. All calculations were done using R software (R Core Team, 2017).

\section{RESULTS}

\section{Total leaf surface area}

The results for the measured variable "total leaf surface area" (Table 1) show that the leaves of the Syrah cultivar were significantly larger (20 $624.38 \mathrm{~mm}^{2}$ for Syrah vs $15079.41 \mathrm{~mm}^{2}$ for Grenache Noir $)(P \leq 0.05)$.

\section{Density of stomata and stomatal index}

No significant difference was seen between the cultivars with respect to the density of stomata (Table 2); Grenache Noir leaves contained 137.75 stomatal pores per $\mathrm{mm}^{2}$, whereas Syrah contained 148.80 pores per $\mathrm{mm}^{2}$. However, the Grenache Noir leaves had a significantly larger stomatal index $(P \leq 0.05)$, i.e. they possessed fewer epidermal cells per number of stomata (Table 2). In addition, the Grenache Noir stomata were significantly longer $(31.40 \mu \mathrm{m}$ in Grenache Noir versus $28.21 \mu \mathrm{m}$ in Syrah) $(P \leq 0.001)$, and the surface area (in transverse section) of the guard cells was also significantly larger in Grenache Noir $(P \leq 0.001)$ (Table 2$)$.

The stomata were distributed in a dispersed manner on the underside of the leaf in both cultivars. In both cultivars, the epidermal cells surrounding the guard cells looked no different from the epidermal cells themselves (Fig. 2), while the guard cells were kidney shaped and lay either at the same level as the epidermal cells or slightly raised (Fig. 2). In transverse section, the cuticles of the guard cells showed thickenings near the stoma (Fig. 2c \& 2e).

\section{Leaf anatomy}

The total thickness of the leaf blade was significantly $(P \leq 0.01)$ greater in the Grenache Noir cultivar (Table 3$)$ (245.18 $\mu \mathrm{m} v \mathrm{vs} 193.01 \mu \mathrm{m}$ for Syrah). No difference was seen between the cultivars either in upper or lower cuticle thickness (Table 1, Fig. 3), but in both cultivars the lower cuticle was thicker than the upper cuticle (Fig. 3), and significantly so in Grenache Noir $(3.58 \mu \mathrm{m}$ for lower cuticle vs $2.69 \mu \mathrm{m}$ for upper cuticle) (Table 1). The Grenache Noir leaves also had a significantly $(P \leq 0.001)$ thicker upper epidermis. The proportion of palisade parenchyma in the

TABLE 1

Leaf area and thickness of the upper and lower cuticles in the grapevine cultivars Grenache Noir and Syrah.

\begin{tabular}{llll}
\hline Cultivar & Leaf area $\left(\mathrm{mm}^{2}\right)$ & Upper cuticle thickness $(\mu \mathrm{m})$ & Lower cuticle thickness $(\mu \mathrm{m})$ \\
\hline Grenache Noir & $15079.41 \pm 1253.78$ & $2.69 \pm 0.29$ & $3.58 \pm 0.19$ \\
Syrah & $20624.38 \pm 1232.87$ & $3.30 \pm 0.08$ & $3.34 \pm 0.09$ \\
n & 5 & 10 & 10 \\
Sig. & $*$ & ns & ns \\
\hline
\end{tabular}

Data show mean $\pm \mathrm{SE}$ (standard error of the mean). $\mathrm{n}=$ number of measurements.

Sig. $=$ significance, $\mathrm{ns}=$ not significant, ${ }^{*} \mathrm{p} \leq 0.05, * * \mathrm{p} \leq 0.01, * * * \mathrm{p} \leq 0.001$ 
TABLE 2

Stomatal density and size of Grenache Noir and Syrah leaves.

\begin{tabular}{|c|c|c|c|c|c|}
\hline \multirow[t]{2}{*}{ Cultivar } & \multirow{2}{*}{$\begin{array}{l}\text { Stomatal density } \\
\left(\text { No. stomata } \mathrm{mm}^{-2}\right)\end{array}$} & \multirow[t]{2}{*}{ Stomatal index $(\%)$} & \multirow[t]{2}{*}{ Stomatal length $(\mu \mathrm{m})$} & \multicolumn{2}{|c|}{ Guard cell area $\left(\mu \mathrm{m}^{2}\right)$} \\
\hline & & & & Guard cell 1 & Guard cell 2 \\
\hline Grenache Noir & $137.75 \pm 6.26$ & $13.89 \pm 1.71$ & $31.40 \pm 0.68$ & $113.16 \pm 4.56$ & $114.15 \pm 4.70$ \\
\hline Syrah & $148.80 \pm 7.36$ & $8.24 \pm 0.81$ & $28.21 \pm 0.51$ & $79.39 \pm 1.95$ & $80.45 \pm 1.94$ \\
\hline $\mathrm{n}$ & 6 & 6 & 60 & 30 & 30 \\
\hline Sig. & ns & $*$ & $* * *$ & $* * *$ & $* * *$ \\
\hline
\end{tabular}

Guard cell area $\left(\mu \mathrm{m}^{2}\right)$ measured in transverse sections; stomatal length measured from nail polish prints.

Data show mean \pm SE; $\mathrm{n}=$ number of measurements. Sig. = significance, $\mathrm{ns}=$ not significant, ${ }^{*} \mathrm{p} \leq 0.05, * * \mathrm{p} \leq 0.01,{ }^{*} * \mathrm{p} \leq 0.001$

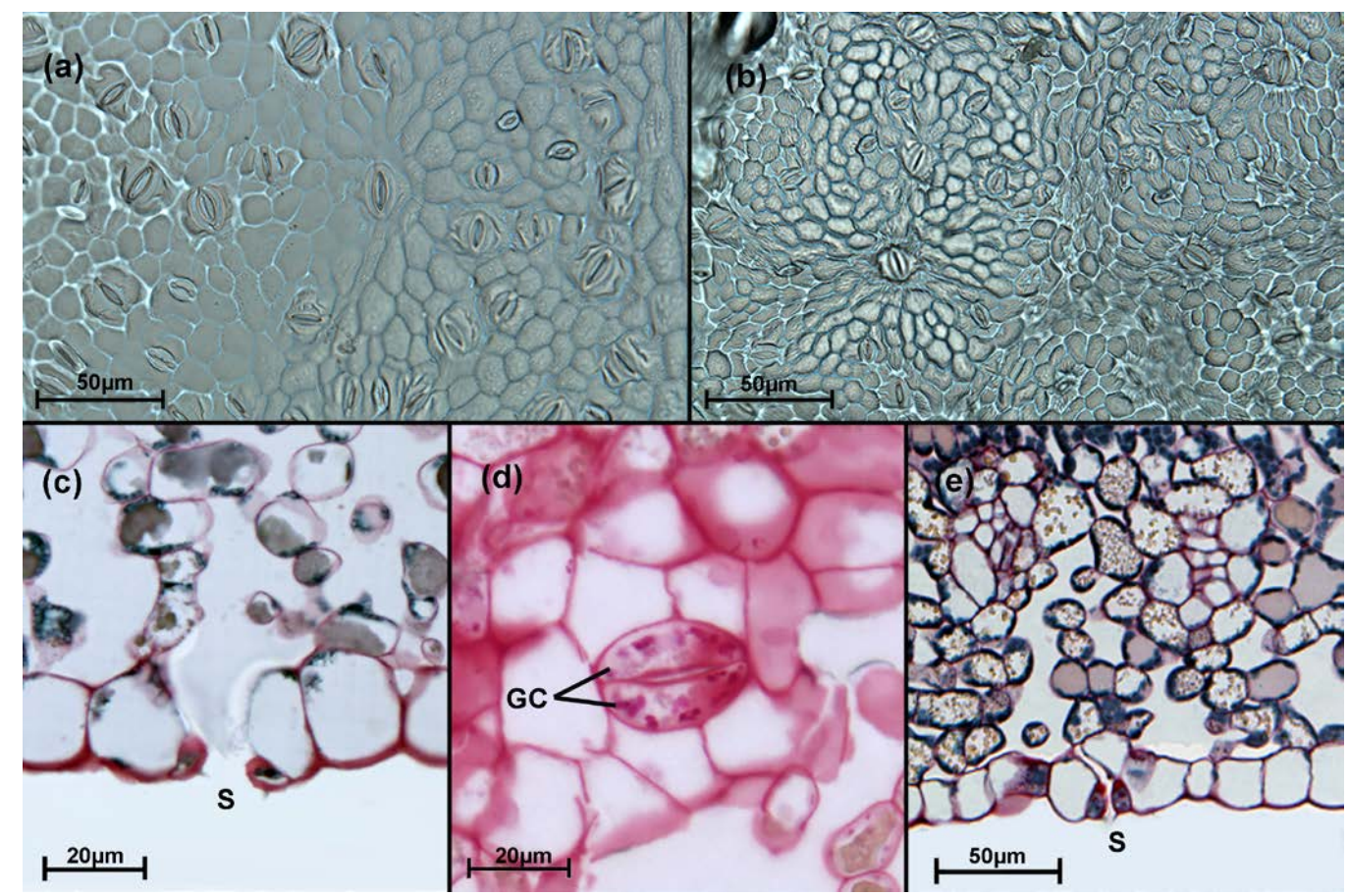

FIGURE 2

Stomata on the abaxial side of the leaves: (a) print of Grenache Noir; (b) print of Syrah, (c and e) bright field image of a transverse section of a stoma stained with PAS+NBB [c = Grenache Noir; e = Syrah]; note the curved thickening of the guard cell outer wall; (d) bright field image of a longitudinal section of a stoma stained with PAS in Grenache Noir. GC = guard cells,

$\mathrm{S}=$ stomata.

total leaf blade thickness was significantly $(P \leq 0.01)$ thicker in the Syrah leaves ( $\mu \mathrm{m} 27.67 \%$ vs. $23.32 \%$ for Grenache Noir) (Table 3).

Examination of the transverse sections of the leaf blade revealed the overall organisation of the leaf tissues to be similar in both cultivars. The abaxial surface of the Syrah leaves presented two types of non-glandular trichomes: prostrate trichomes (were present with a medium density [OIV, 2009]) and erect trichomes (very low density [OIV, 2009]), while the Grenache Noir leaves were glabrous, i.e. they showed neither type. In both cultivars the cuticle on the epidermal cells formed a protective layer over the whole leaf blade (Fig. 3), even covering the trichomes on the abaxial surface of the Syrah leaves (Fig. 4). The mesophyll of both cultivars was dorsiventrally orientated (with the palisade mesophyll adaxial with respect to the spongy parenchyma) (Fig. 4). The spongy parenchyma contained large lacunae in both cultivars, although no significant difference was seen between them in terms of the area occupied by these spaces.

The mesophyll of both cultivars contained needleshaped calcium oxalate crystals called raphides, lying within specialised cells or idioblasts (Fig. 5). Positive periodic acid-Schiff (PAS) staining in all cells containing raphide bundles indicated that the calcium oxalate crystals were totally covered in mucilage polysaccharides (Fig. 5). The idioblasts were more common at the interface between the two types of mesophyll parenchyma (Fig. 5), although they were also seen in both cell layers. The Syrah leaves showed significantly $(P \leq 0.05)$ more idioblasts per unit of cross- 


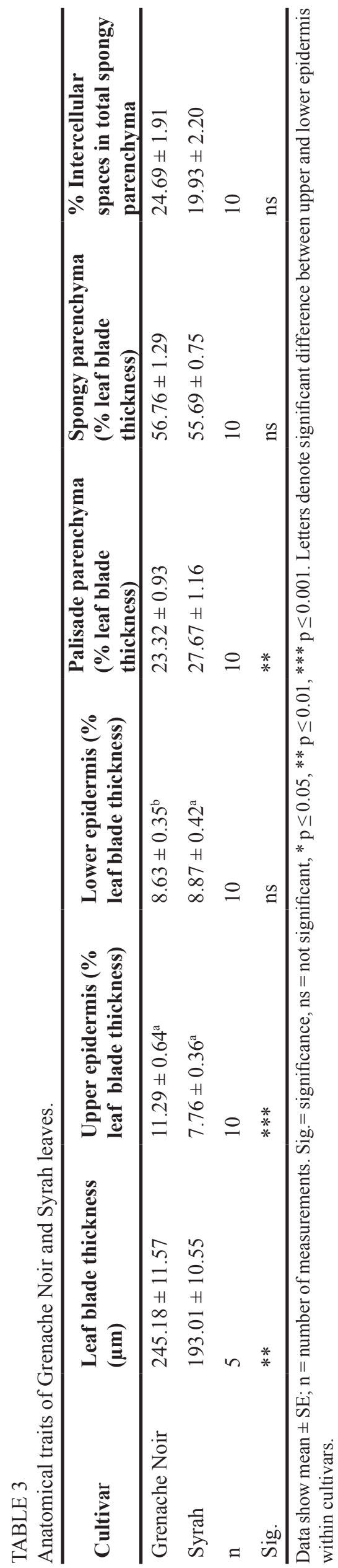

sectional area (5.70 idioblasts per $\left.\mathrm{mm}^{2}\right)$ than the Grenache Noir (3.75 idioblasts per $\mathrm{mm}^{2}$ ). The length of the raphides was similar in both cultivars, but they were significantly $(P \leq 0.01)$ wider in Grenache Noir (Table 4).

\section{DISCUSSION}

The present results reveal anatomical and morphological differences between the leaves of the studied cultivars. Both stomatal anatomy and density have been well studied in Vitis leaves, since they appear to be related to resistance to drought and certain fungal infections (Boso et al., 2010; Gerzon et al., 2015). However, different authors have recorded different stomatal density values for both Grenache Noir and Syrah (Gómez-del-Campo et al., 2003; Rogiers et al., 2009; Monteiro et al., 2013; Gerzon et al., 2015). This might be explained by differences in experimental conditions: some of these reports examined plants in pots, while others examined plants in greenhouses and in the field. Scienza and Boselli (1981) reported clear differences in the stomatal density of rootstock cultivars grown in pots and in the field. Gerzon et al. (2015) reported the differences in stomatal density between Grenache Noir and Syrah plants grown in pots to be greater than between plants grown in the field. In addition, they reported the stomatal density of Grenache Noir to be significantly higher, with no differences seen in terms of stoma length. In the present work, no difference was seen between the cultivars in terms of stomatal density, but the stomata of Grenache Noir were significantly longer and wider. In addition, the stomatal index of the present Grenache Noir plants was significantly greater than that of the Syrah plants. However, caution should be taken when comparing stomatal density data collected by different authors; discrepancies in these results may be due to differences in the stage of development of the plants and the environmental conditions under which they were grown (Yan et al., 2017). Stoma size would appear to be a genetically controlled trait, but further work is needed to determine whether this variable is affected by ecophysiological features, while stomatal index (SI) is a direct measure of the proportion of epidermal cells that have differentiated into stomata. Therefore, SI measurements allow a normalisation of the effects of epidermal cell size, whereas stomatal density is influenced by epidermal cell size, which could be modified by environmental factors (Yan et al., 2017).

The presence of trichomes in the abaxial surface of the leaves of the Syrah cultivar agree with the results reported by Boso et al. (2010) and Gago et al. (2016), and the trichome type (erect and/or prostrate), their microanatomy and distribution on the abaxial epidermis are consistent with that reported previously by Gago et al. (2016). Also, the structures recorded for the two epidermises and the organisation of the mesophyll tissues agree with results reported by Boso et al. (2010) for different cultivars of $V$. vinifera and the species $V$. riparia. Monteiro et al. (2013) describe the palisade parenchyma of several red grape cultivars to be 'pluristratified', with up to three layers of compact cells. In the present work, however, the palisade parenchyma of both Grenache Noir and Syrah was composed of just one layer. In some transverse sections, however, an intermediate layer of very compact cells was seen at the palisade/ 

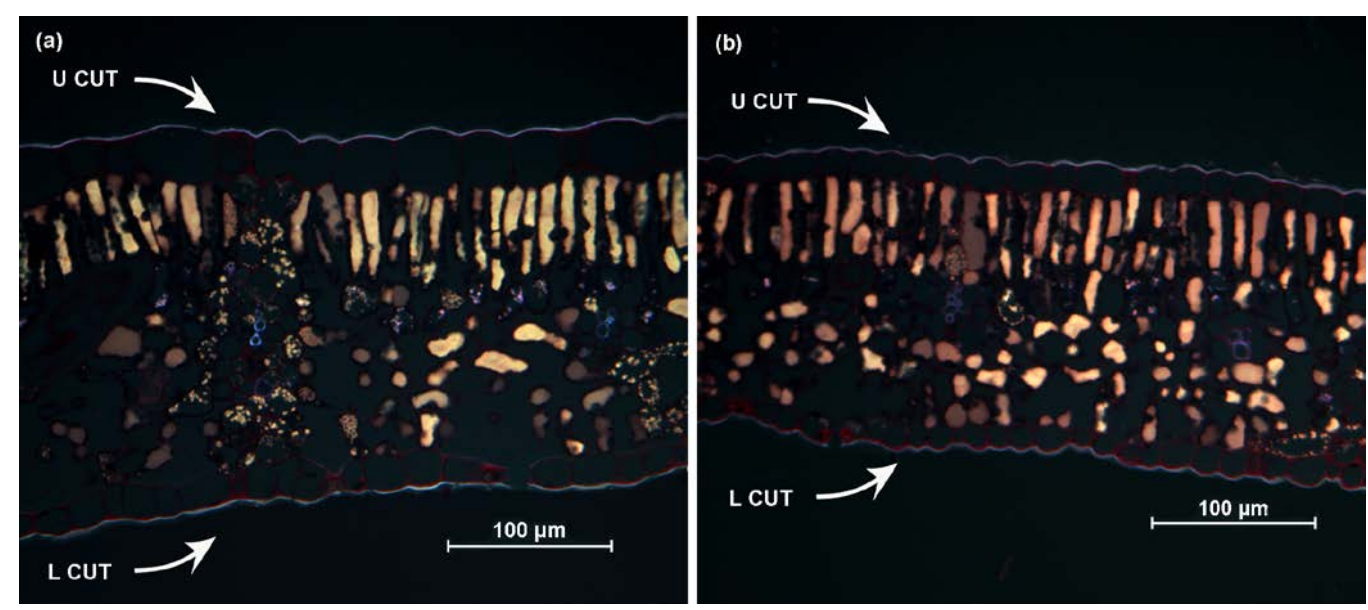

FIGURE 3

Cuticle on the leaf epidermis: (a): epifluorescence microscopy image of a transverse section of Grenache Noir (note upper and lower epidermises); (b): bright field image of a longitudinal section of Syrah leaf stained with PAS. UCUT = upper cuticle,

\section{LCUT $=$ lower cuticle}

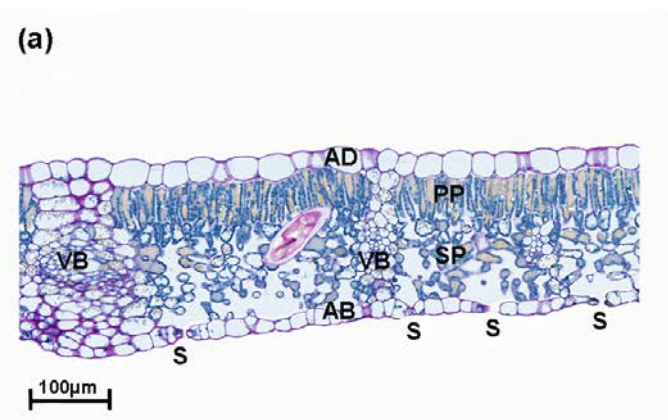

(b)

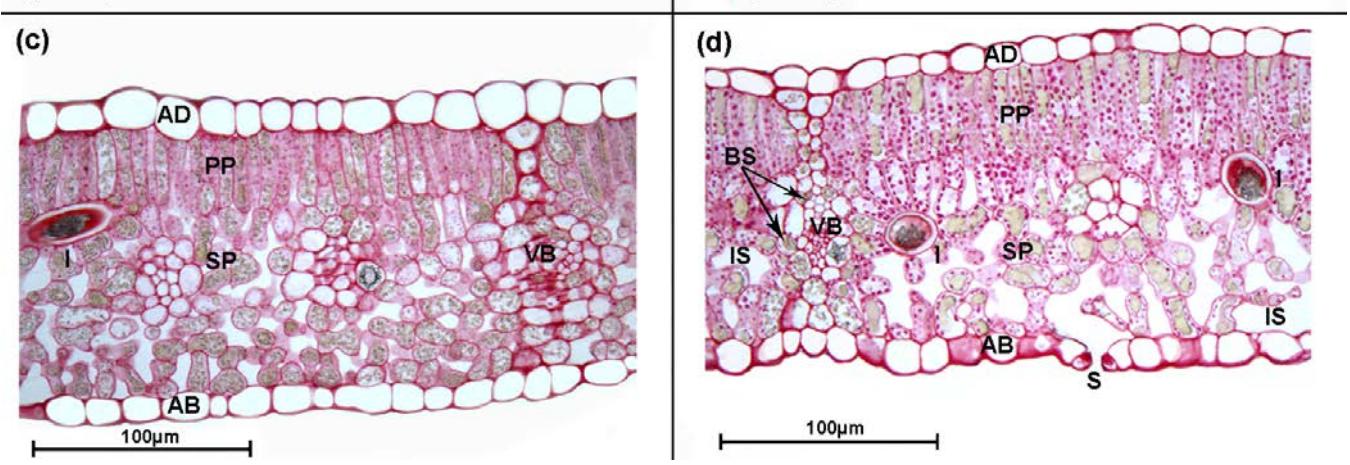

FIGURE 4

Leaf anatomical characteristics as seen in transverse section (staining with PAS+NBB), (a) Grenache, (b) Syrah. PAS staining of Grenache (c) and Syrah (d) leaves. AB, abaxial epidermis; AD, adaxial epidermis; BS, bundle sheath; I, idioblast; IS, intercellular space; PP, palisade parenchyma; S, stomata; SP, spongy parenchyma; T, trichome; TB, trichome base; VB, vascular bundle.

spongy parenchyma interface - cells considered here as not belonging to the palisade parenchyma. Rather, this layer appears to be made up of apoptotic cells that eventually give rise to lacunae. The apoptosis gradient begins close to the lower epidermis; the cells closest to the palisade parenchyma are the last to experience any apoptotic events. This gives rise to fewer lacunae among these cells and the creation of this intermediate layer of cells.

Grenache Noir and Syrah have shown different stomatal control behaviour under water stress conditions (Schultz,
2003; Santesteban et al., 2009), and for this they have been classified as either isohydric (Grenache Noir) or anisohydric (Syrah). Differences in the anatomy of the petioles, green shoots and rachis of their clusters have previously been noted between the isohydric Grenache Noir and the anisohydric Syrah (Schultz, 2003; Gerzon et al., 2015; Scharwies \&Tyerman, 2017). In the present work, anatomical differences were detected in the leaves that might play some functional role in the regulation of leaf water potential $\left(\Psi_{L}\right)$. The total thickness of the Grenache Noir leaves was 
TABLE 4

Idioblasts and their calcium oxalate crystal/mucilage content variables.

\begin{tabular}{|c|c|c|c|c|c|}
\hline & Grenache Noir & $\mathbf{n}$ & Syrah & $\mathbf{n}$ & Sig. \\
\hline $\begin{array}{l}\text { Number of idioblasts per cross-sectional area } \\
\text { of the leaf }\left(\mathrm{No} . \mathrm{mm}^{-2}\right)\end{array}$ & $3.75 \pm 0.51$ & 5 & $5.70 \pm 0.46$ & 5 & $*$ \\
\hline \multicolumn{6}{|l|}{ Idioblast dimensions (longitudinal section): } \\
\hline Perimeter $(\mu \mathrm{m})$ & $208.61 \pm 21.07$ & 13 & $230.62 \pm 20.27$ & 8 & ns \\
\hline Length $(\mu \mathrm{m})$ & $88.09 \pm 10.39$ & 13 & $99.00 \pm 9.32$ & 8 & ns \\
\hline Width $(\mu \mathrm{m})$ & $29.77 \pm 1.52$ & 13 & $27.52 \pm 1.85$ & 8 & ns \\
\hline Area $\left(\mu \mathrm{m}^{2}\right)$ & $2337.69 \pm 346.63$ & 13 & $2475.00 \pm 347.06$ & 8 & ns \\
\hline \multicolumn{6}{|l|}{ Idioblast dimensions (transverse section): } \\
\hline Perimeter $(\mu \mathrm{m})$ & $109.87 \pm 3.78$ & 28 & $95.63 \pm 2.45$ & 46 & $* *$ \\
\hline Diameter $(\mu \mathrm{m})$ & $27.77 \pm 0.82$ & 28 & $25.01 \pm 0.54$ & 46 & $* *$ \\
\hline $\operatorname{Area}\left(\mu \mathrm{m}^{2}\right)$ & $916.68 \pm 60.69$ & 28 & $694.74 \pm 33.71$ & 46 & $* *$ \\
\hline
\end{tabular}

(a)
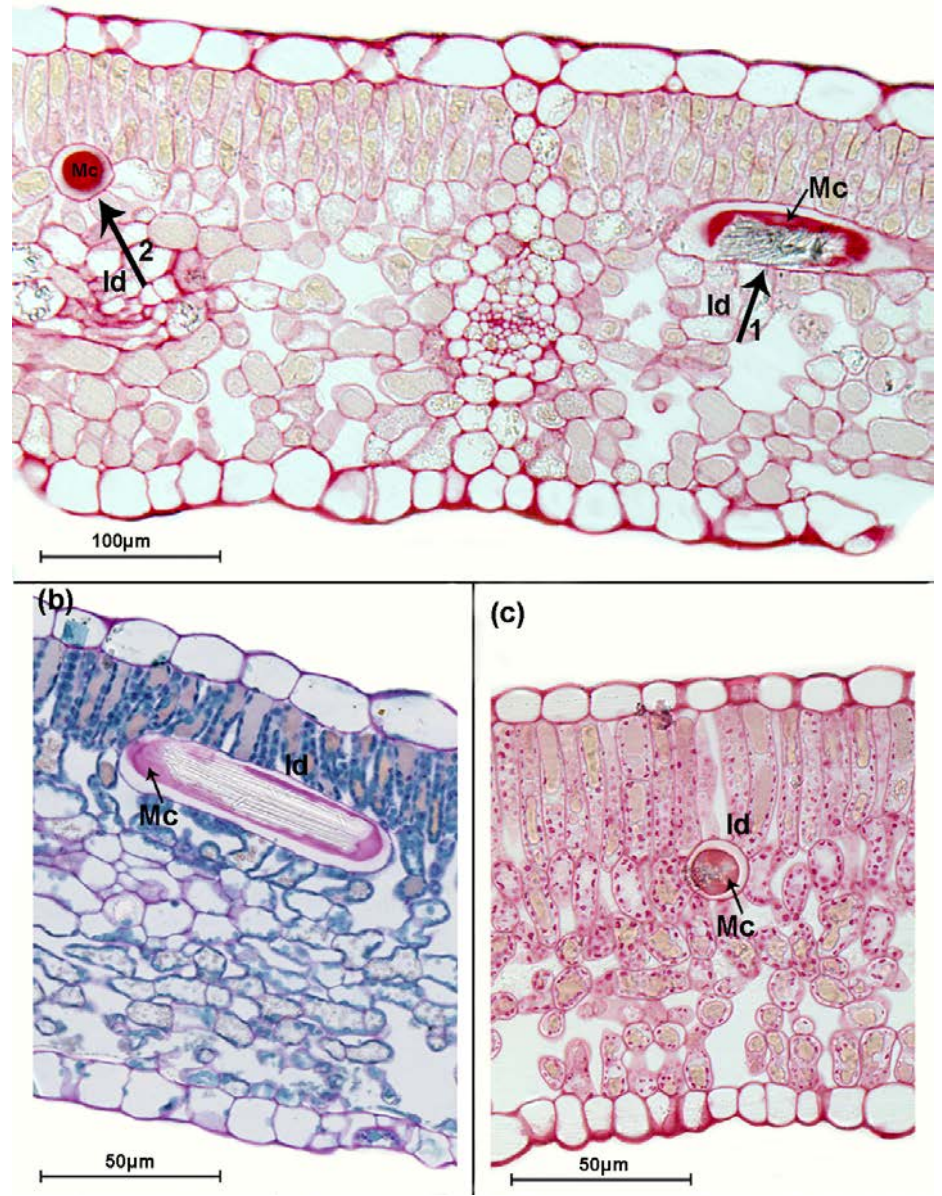

FIGURE 5

Idioblast cells containing calcium oxalate crystals grouped in raphide bundles and mucilage. The idioblast cells are oriented in different directions. (a) Transverse section of Grenache Noir leaf stained with PAS: arrow No. 1 shows longitudinal section of an idioblast with the crystals as raphides embedded in mucilage (stained in red with PAS reagent); arrow No. 2 shows a transverse section of a similar idioblast. (b) Transverse section of Grenache Noir leaf stained with PAS+NBB showing longitudinal image of an idioblast cell containing a bundle of raphides embedded in mucilage. (c) Transverse section of a Syrah leaf stained with PAS showing a transverse image of idioblast containing raphides and mucilage. Mc, mucilage; Id, idioblast cells containing raphides (calcium oxalate crystals). 
significantly greater than that of the Syrah leaves, but the thickness of the palisade parenchyma was greater in Syrah. A thicker palisade tissue would increase the number of sites available for $\mathrm{CO}_{2}$ assimilation per unit area of leaf surface (Ennajeh et al., 2010), and may help maintain photosynthetic assimilation rates for some time if the stomata were to close in order to retain water. The Grenache Noir leaves had a smaller total surface area than the Syrah leaves - another adaptation that has been related to drought tolerance (Doupis et al., 2016). The leaves of these two cultivars thus show anatomical and morphological adaptations that might be related to tolerance to water stress.

More recently published work shows the anisohydric classification of Syrah may not be so certain (Rogiers et al., 2011; Coupel-Ledru et al., 2014; Hugalde \& Vila 2014; Gerzon et al., 2015). The existence of a relationship between water potential and stomatal conductance is questioned, since a cultivar may show isohydric or anisohydric behaviour depending on the degree of water stress and environmental conditions (Lovisolo et al., 2010). Mishra et al. (2012) reported that certain morphological characteristics of Arabidopsis thaliana leaves, including their shape and size, vary depending upon whether plants were grown inside or outside growth chambers. Experiments have been performed in grapevine plants grown in pots under glasshouse conditions, in the field, and grafted or not onto rootstocks, and different results were obtained for the same variables. For example, Hochberg et al. (2018) suggest that grapevine plants shift from anisohydric to isohydric depending on soil water potential, so for proper characterisation of the genotypic effect (iso/anisohydric) it is also important to consider the effect of the environment. In order to enable meaningful comparisons of different cultivars, it is also necessary to improve our understanding of the temporal dimension of drought responses and the role of anatomical traits related to water transport in the plant (Martínez-Vilalta \& García-Forner, 2017).

Many idioblasts were found in the leaf mesophyll of both the Grenache Noir and Syrah plants. These cells accumulate calcium oxalate and mucilage, and were more commonly seen at the interface of the palisade and spongy parenchyma. The calcium in these crystals is of environmental origin and from the oxalate synthesised by the cells (Franceschi \& Nakata, 2005). The morphology of these crystal-containing cells has been used in the taxonomic classification of plant species (Pennisi \& McConnell, 2001; Coutinho et al., 2013). Their function is not entirely clear, but it has been proposed that they are involved in tissue calcium regulation, protection from herbivores, and heavy metal detoxification (Franceschi \& Nakata 2005; He et al., 2013). Other authors suggest that these crystals, plus the mucilage found in these cells, might have a functional role in water stress. For example, Brown et al. (2013), who studied the leaflets of different Acacia species, reported an increase in the accumulation of these crystals when soil water levels were maintained at low levels. Liu et al. (2015) report the presence of idioblasts containing crystals and mucilage in mature Populus euphratica leaves and attribute them a function in drought resistance, with the mucilage at least helping in the storage of water in the mesophyll. Similarly, Doupis et al. (2016) reported idioblasts containing mucilage and calcium oxalate to increase in number in grapevine leaves growing under water stress conditions. These authors suggest that the mucilage permits rapid water accumulation in the leaf mesophyll that can be released when needed. Finally, Tooulakou et al. (2016) monitored the oxalate content to examine the fluctuation in calcium oxalate crystal volume over the course of a day in Amaranthus hybridus, and proposed that these crystals act as a source of carboxyl groups that could be turned into $\mathrm{CO}_{2}$ by the enzyme oxalate oxidase during times when the atmospheric supply of the gas is low, e.g. when the stomata are closed in reaction to water stress. The accumulation of calcium oxalate crystals may therefore provide the plant with a means of tolerating drought.

In the present work, the cultivar Syrah had the larger number of idioblasts, but the crystals carried by those of Grenache Noir were bigger. However, their abundance and size were studied only in transverse sections of the leaves. To establish the relationship between the accumulation of calcium oxalate + mucilage and tolerance to water stress, further work is necessary on the size and distribution of the idioblasts containing them, and comparisons have to be made between plants subjected to different degrees of water stress.

\section{CONCLUSIONS}

Anatomical and morphological differences were found between the leaves of the Grenache Noir and Syrah grapevine cultivars, with the former showing smaller but thicker leaves. Differences were also detected in terms of the distribution of their leaf mesophyll tissues, stomatal size and index, and the abundance of idioblasts. The functional significance of these differences, however, remains to be determined. Indeed, further work is needed to determine how plastic these differences might be in plants growing under water stress conditions.

\section{LITERATURE CITED}

Anderson, K. \& Aryal, N.R., 2013. Database of regional, national and global winegrape bearing areas by variety, 2000 and 2010. Wine Economics Research Centre, University of Adelaide. Online: http//www.adelaide.edu. au/wine-econ/databases/winegrapes/ [accessed 4 November 2017].

Ben Salem-Fnayou, A., Bouamama, B., Ghorbel, A. \& Mliki, A., 2011. Investigations on the leaf anatomy and ultrastructure of grapevine (Vitis vinifera L.) under heat stress. Microsc. Res. Techniq. 74(8), 756-762.

Boso, S., Alonso-Villaverde, V., Santiago, J.L., Gago, P., Dürrenberger, M., Düggelin, M., Kassemeyer, H.H. \& Martinez, M.C., 2010. Macro- and microscopic leaf characteristics of six grapevine cultivars (Vitis spp) with different susceptibilities to grapevine downy mildew. Vitis 49, 43-50.

Brown, S.L., Warwick, N.W.M. \& Prychid, C.J., 2013. Does aridity influence the morphology, distribution and accumulation of calcium oxalate crystals in Acacia (Leguminosae, Mimosoideae)? Plant Physiol. Bioch. 73, 219-228.

Buffard-Morel, J., Verdeil, J. \& Pannetier, C., 1992. Embryogenèses somatique du cocotier (Cocos nucifera $\mathrm{L}$ ) à partir de tissus foliaires, étude histologique. Can. J. Bot. 70, 735-741.

Coupel-Ledru, A., Lebon, E., Christophe, A., Doligez, A., Cabrera-Bosquet, L., Pechier, P., Hamard, P., This, P. \& Simonneau, T., 2014. Genetic variation in a grapevine progeny (Vitis vinifera L cvs Grenache NoirxSyrah) reveals inconsistencies between maintenance of daytime leaf water potential and response of transpiration rate under drought. J. Exp. Bot. 65(21), 6205-6218. 
Coutinho, I.A.C., Francino, D.M.T. \& Meira, R.M.S.A., 2013. Leaf anatomical studies of Chamaecrista subsect Baseophyllum (Leguminosae, Caesalpinioideae), new evidence for the up-ranking of the varieties to the species level. Plant Syst. Evol. 299(9), 1709-1720.

D’Ambrogio de Argüeso, A., 1986. Manual de técnicas en Histología Vegetal. Ed Hemisferio Sur SA, Buenos Aires.

Doupis, G., Bosabalidis, A.M. \& Patakas, A., 2016. Comparative effects of water deficit and enhanced UV-B radiation on photosynthetic capacity and leaf anatomy traits of two grapevine (Vitis vinifera L) cultivars. Theor. Exp. Plant Phys. 28, 131-141.

Ennajeh, M., Vadel, A.M., Cochard, H. \& Khemira, H., 2010. Comparative impacts of water stress on the leaf anatomy of a drought-resistant and a drought-sensitive olive cultivar. J Hortic. Sci. Biotech. 85(4), 289-294.

Fisher, D., 1968. Protein staining of ribboned epon sections for light microscopy. Histochemie 16, 92-96.

Franceschi, V.R. \& Nakata, P.A., 2005. Calcium oxalate in plants: Formation and function. Annu. Rev. Plant Biol. 56, 41-71.

Gago, P., Conejero, G., Martinez, M.C., Boso, S., This, P. \& Verdeil, J.L., 2016. Microanatomy of leaf trichomes, opportunities for improved ampelographic discrimination of grapevine (Vitis vinifera $\mathrm{L}$ ) cultivars. Aust. J. Grape Wine R. 22(3), 494-503.

Gerzon, E., Biton, I., Yaniv, Y., Zemach, H., Netzer, Y., Schwartz, A., Fait, A. \& Ben-Ari, G., 2015. Grapevine anatomy as a possible determinant of isohydric or anisohydric behavior. Am. J. Enol. Viticult. 66(3), 340-347.

Gómez-del-Campo, M., Ruiz, C., Baeza, P. \& Lissarrague, J.R., 2003. Drought adaptation strategies of four grapevine cultivars (Vitis vinifera $\mathrm{L}$ ), modification of the properties of the leaf area. J. Int. Sci. Vigne Vin 37(3), 131-143.

He, H., Veneklaas, E.J., Kuo, J. \& Lambers, H., 2014. Physiological and ecological significance of biomineralization in plants. Trends Plant Sci. 19, 166-174.

Hochberg, U., Rockwell, F.E., Holbrook, N.M. \& Cochard, H., 2018. Iso/ anisohydry: A plant-environment interaction rather than a simple hydraulic trait. Trends Plant Sci. 23(2), 112-120.

Hugalde, I.P. \& Vila, H.F., 2014. Comportamiento isohídrico o anisohídrico en vides..., ¿Una controversia sin fin? Revista de Investigaciones Agropecuarias 40, 75-82

Liu, Y., Li, X., Chen, G., Li, M., Liu, M. \& Liuy, D., 2015. Epidermal micromorphology and mesophyll structure of Populus euphratica heteromorphic leaves at different development stages. Plos One 10, e0141578.

Lovisolo, C., Perrone, I., Carra, A., Ferrandino, A., Flexas, J., Medrano, H. \& Schubert, A., 2010. Drought-induced changes in development and function of grapevine (Vitis spp) organs and in their hydraulic and non-hydraulic interactions at the whole-plant level, a physiological and molecular update. Funct. Plant Biol. 37(2), 98-116.

Martínez-Vilalta, J. \& García-Forner, N., 2017. Water potential regulation, stomatal behaviour and hydraulic transport under drought: Deconstructing the iso/anisohydric concept. Plant Cell Environ. 40, 962-976.

Mishra, Y., Jankanpaa, H.J., Kiss, A.Z., Funk, C., Schroder, W.P. \& Jansson, S. 2012. Arabidopsis plants grown in the field and climate chambers significantly differ in leaf morphology and photosystem components. BMC Plant Biol. 12, 6 .
Monteiro, A., Teixeira, G. \& Lopes, C.M., 2013. Comparative leaf micromorphoanatomy of Vitis vinifera SSP vinifera (Vitaceae) red cultivars. Ciencia e Tec Vitivinic 28(1), 19-28.

Organisation Internationale de la Vigne et du Vin (O.I.V.), 2009 (2nd ed). Code des caractères descriptifs des variétés et espèces de Vitis. Dedon, Paris.

Pennisi, S.V. \& McConnell, D.B., 2001. Taxonomic relevance of calcium oxalate cuticular deposits in Dracaena Vand ex L. Hortscience 36, 1033 1036

R Core Team, 2017. R, a language and environment for statistical computing. R Foundation for Statistical Computing, Vienna, Austria [Online]: https,// wwwR-projectorg/ [accessed 20 July 2017]

Rogiers, S.Y., Greer, D.H., Hatfield, J.M., Hutton, R.J., Clarke, S.J., Hutchinson, P.A. \& Somers, A., 2011. Stomatal response of anisohydric grapevine cultivar to evaporative demand, available soil moisture and abscisic acid. Tree Physiol. 32, 249-261.

Rogiers, S.Y., Greer, D.H., Hutton, R.J. \& Landsberg, J.J., 2009. Does night-time transpiration contribute to anisohydric behaviour in a Vitis vinifera cultivar? J. Exp. Bot. 60(13), 3751-3763.

Santesteban, L.G., Miranda, C. \& Royo, J.B., 2009. Effect of water deficit and rewatering on leaf gas exchange and transpiration decline of excised leaves of four grapevine (Vitis vinifera L) cultivars. Sci. Hortic. 121, 434439 .

Scharwies, J.D. \& Tyerman, S.D., 2017. Comparison of isohydric and anisohydric Vitis vinifera L. cultivars reveals a fine balance between hydraulic resistances, driving forces and transpiration in ripening berries. Funct. Plant Biol. 44(3), 324-338.

Schultz, H.R., 2003. Differences in hydraulic architecture account for near isohydric and anisohydric behaviour of two field grown Vitis vinifera L cultivars during drought. Plant Cell Environ. 26(8), 1393-1405.

Scienza, A. \& Boselli, M., 1981. Fréquence et caractéristiques biométriques des stomates de certains porte-greffes de vigne. Vitis 20, 281-292.

Tardieu, F. \& Simonneau, T., 1998. Variability among species of stomatal control under fluctuating soil water status and evaporative demand: Modelling isohydric and anisohydric behaviours. J. Exp. Bot. 49, 419-432.

Tombesi, S., Nardini, A., Farinelli, D. \& Palliotti, A., 2014. Relationships between stomatal behavior, xylem vulnerability to cavitation and leaf water relations in two cultivars of Vitis vinifera. Physiol. Plantarum 152(3), 453464.

Tooulakou, G., Giannopoulos, A., Nikolopoulos, D., Bresta, P., Dotsika, E., Orkoula, M.G., Kontoyannis, C.G., Fasseas, C., Liakopoulos, G., Klapa, M.I. \& Karabourniotis, G., 2016. Alarm photosynthesis, calcium oxalate crystals as an internal $\mathrm{CO}_{2}$ source in plants. Plant Physiol. 171(4), 2577 2585 .

Vezzulli, S., Troggio, M., Coppola, G., Jermakow, A., Cartwright, D., Zharkikh, A., Stefanini, M., Grando, M.S., Viola, R., Adam-Blondon, A.F., Thomas, M., This, P. \& Velasco, R., 2008. A reference integrated map for cultivated grapevine (Vitis vinifera L) from three crosses, based on 283 SSR and 501 SNP-based markers. Theor. Appl. Genet. 117(4), 499-511.

Wilkinson, H., 1979 ( $2^{\text {nd }}$ ed). The plant surface. In Metcalfe, C.R. \& Chalk, L. (eds). Anatomy of dicotyledons, vol 1, Systematic anatomy of the leaf and stem. Clarendon Press, Oxford. pp. $97-165$.

Yan, W.M., Zhong, Y.Q.W. \& Shangguan, Z.P., 2017. Contrasting responses of leaf stomatal characteristics to climate change: A considerable challenge to predict carbon and water cycles. Global Change Biol. 23(9), 3781-3793. 